\title{
Quality assessment of flour and cookies from wheat, African yam bean and acha flours
}

\author{
1,*Adeyanju, J.A., ${ }^{2}$ Babarinde, G.O., ${ }^{2}$ Olanipekun, B.F., ${ }^{2}$ Bolarinwa, I.F. and \\ ${ }^{2}$ Oladokun, S.O. \\ ${ }^{1}$ Department of Food Engineering, Ladoke Akintola University of Technology, P. M. B. 4000, Ogbomoso, \\ Oyo State, Nigeria \\ ${ }^{2}$ Department of Food Science, Ladoke Akintola University of Technology, P. M. B. 4000, Ogbomoso, Oyo \\ State, Nigeria
}

\begin{abstract}
Article history:
Received: 21 July 2020

Received in revised form: 31

August 2020

Accepted: 31 October 2020

Available Online: 17 January 2021
\end{abstract}

Keywords:

Acha,

African yam bean,

Cookies,

Wheat,

Anti-nutrients,

Quality attributes

\section{DOI:}

https://doi.org/10.26656/fr.2017.5(1).370

\begin{abstract}
In this study, the suitability of wheat, acha and African yam bean composite flour in the development of cookies was investigated. Wheat, acha and African yam bean were blended into various proportions of flour mixes and used to produce cookies. The flour mixes were analyzed for the proximate, minerals composition, functional properties and anti-nutrients, while the cookies were evaluated for its sensory and physical properties. The proximate composition of the flours varied from 7.85-9.71\%, 12.34-14.01\%, 1.15$1.86 \%, 1.21-1.49 \%, 1.65-1.92 \%$ and $70.01-76.11 \%$ for moisture, protein, fat, crude fiber, ash and carbohydrate content of the flour, respectively. The mineral content ranged from $10.11-13.12 \mathrm{mg} / 100 \mathrm{~g}, 52.65-61.76 \mathrm{mg} / 100 \mathrm{~g}, 130.71-211.76 \mathrm{mg} / 100 \mathrm{~g}, 111.97-130.84$ $\mathrm{mg} / 100 \mathrm{~g}$ and 14.81-20.43 mg/100 $\mathrm{g}$ for calcium, magnesium, potassium, phosphorus and sodium, respectively. The functional properties ranged from $0.76-0.80 \mathrm{~g} / \mathrm{cm}^{3} ; 86.65-$ $188.11 \mathrm{~g} / \mathrm{g} ; 94.30-197.23 \mathrm{~g} / \mathrm{g} ; 569.23-699.54 \% ; 5.68-6.44 \% ; 61.50-125.50 \mathrm{sec}, 73.75-$ $75.25 \%$ for bulk density, water absorption capacity, oil absorption capacity, swelling capacity, solubility, wettability and dispersiblity respectively. The anti-nutritional properties ranged from 37.67 to $46.73 \mathrm{mg} / 100 \mathrm{~g}, 5.27$ to $5.57 \mathrm{mg} / 100 \mathrm{~g}$ and 32.91 to 35.10 $\mathrm{mg} / 100 \mathrm{~g}$ for oxalate, phytate and tannin, respectively. The physical properties values ranged from 6.11-8.20 mm, 38.46-39.30 mm, 37.83-38.23 mm, 4.79-5.85, 5.35-7.49 $\mathrm{g}$ and $1.72-1.90 \mathrm{~kg}$ for thickness, diameter, height, spread ratio, weight and break strength respectively. Cookies from composite flours were not significantly $(p>0.05)$ different from the control in overall acceptability. This shows the possibility of producing nutritious cookies with desirable organoleptic qualities from wheat, acha and African yam bean flour.
\end{abstract}

\section{Introduction}

Biscuits or cookies are one of the popular cereal foods, consumed in Nigeria. They are instant, fast and economical food products, with great dietary and digestive principles (Kulkarni, 1997). They are snacks containing high nutrients prepared through the application of heat in the oven where it is transformed into appealing products from rough or unappetizing dough (Olaoye et al., 2007). Majority of these foods products are however poor sources of protein and such contribute to poor nutritional quality (Akpapunam and Darbe, 1994). Being an instant and fast food product, it is important to be enriched with other protein sources such as legumes and oilseeds and fortified with vitamins and minerals (Eltayeb et al., 2011).

Wheat (Triticum aestivum) is one of the most useful and valuable crops grown around the world and it is considered as almost first among cereal largely due to the fact that its grain contains protein with unique chemical and physical properties, and other vital nutrients (Ikhtiar and Alam, 2007). Studies have shown that blending of legume with root crops or cereals could help to improve the overall nutrition in the diet. Wheat flour is the major nutritious plant foods available, offering an array of minerals and critical nutrients. Wheat flour is a powder made from the grinding of wheat used for human consumption. 
Acha (Digitaria exilis) is a cereal crop grown in some areas of Plateau, Kaduna and Bauchi States. Acha is of great nutritional content and this makes it a popular crop with high demand, especially in urban areas where its nutritional importance is known and valued. It contains methionine and cysteine, two amino acids that are important to human survival. These two amino acids, however, are lacking in wheat, rice, maize, and other cereal crops (Adoukonou-Sagbadja et al., 2007). Moving from the amino acid level to the macromolecule level, $D$. exilis, compared to other cereal crops, has greater protein, carbohydrate, and fiber content (Barikmo et al., 2004). However, the production and supply of acha remains low and falls short of its demand. Acha production is unpopular because of the drudgery involved in its harvest and processing. In the traditional way of processing, the acha grains are dehulled by beating, trampling or in a mortar. Acha seeds are additionally very small in size, which makes its winnowing hard to do as sand tends to remain with the seeds, leading to gritty finished/cooked products.

African yam bean (Sphenostylis stenocarpa), an important legume in Africa with duo food product (seeds and tubers) and it is a lesser-known legume of the tropical and sub-tropical areas of the world which has attracted research in recent times (Azeke et al., 2005). African yam bean is rich in carbohydrate, protein, vitamins and minerals (Iwuoha and Eke, 1996). African yam bean consists of protein that is made up of over $32 \%$ essential amino acids, with leucine and lysine being preponderant (Onyenekwe et al., 2000). Therefore, substituting it with wheat in the production of cookies would supply the lysine absent in wheat. This legume has also been reported to be of importance in the management of chronic diseases like hypertension, diabetes, and cardiovascular diseases because of its high dietary fibre content (Enwere, 1998).

In spite of all this, African yam bean is underutilized and hardly consumed in urban areas which are attributed to its complex preparation method. The use of African yam bean in composite flour for cookies production will make it readily available for consumption by all persons. It is a good source of protein, carbohydrate, minerals and vitamins with its protein content, twice that of sweet or Irish potatoes and very much higher than those in yam and cassava (Day, 2013). The utilization of wheat, acha and African yam bean in the production of baked goods are not well known in Nigeria and there is scanty information on the utilization of acha and African yam bean in Nigerian foods since they are both underutilized cereals and legumes respectively. Hence, this study looks into the quality attributes of cookies produced from composite flour from wheat, acha and African yam bean flour.

\section{Materials and methods}

\subsection{Procurement of materials}

African yam bean (AYB) and wheat were purchased from a local market (Bodija) in Ibadan, Oyo State while acha was purchased in Jos, Plateau State. Other ingredients such as sugar, yeast, fat, margarine, egg and baking powder were purchased from Sabo market in Ogbomoso.

\subsection{Preparation of African yam bean and acha flour}

African yam bean flour was prepared according to the methods described by Enwere (1998). The African yam bean (AYB) was cleaned to remove all contaminants such as stones, pods, fragments, immature beans, soaked in water for $12 \mathrm{hrs}$ and blanched for 15 mins to reduce the anti-nutritional factors and beany flavour that might be present. The blanched AYB will then be dehulled and oven-dried at $55^{\circ} \mathrm{C}$ for $12 \mathrm{hrs}$, milled into flour, sieved at $450 \mu \mathrm{m}$ aperture sieve to obtain fine African yam bean flour. Acha flour was prepared according to the methods described by Adegoke (2004) about $2 \mathrm{~kg}$ of acha was washed and then dried on clean sack. The dried acha was milled using a hammer mill, sieved $(300-400 \mu \mathrm{m})$ and then the flour was obtained.

\subsection{Formulation and production of cookies}

Blends with different proportions of wheat flour (WF), acha flour (AF) and African yam bean (AYBF) were prepared with $100 \% \mathrm{WF}$ as control. Cookies were prepared using the method described by Ceserani and Kinton (2008). Fat and sugar were creamed together until fluffy. The flour, baking powder, whole egg and salt were added and manually mixed in a bowl to form a dough. The dough was rolled to a uniform thickness and baked in an oven at $170^{\circ} \mathrm{C}$ for $20 \mathrm{~min}$. The cookies were removed and allowed to cool on a rack, after which they were packaged in low-density polyethylene bags and kept in a plastic container before further analyses.

\subsection{Analyses}

The flour samples were analyzed according to the method described by AOAC (2005) for moisture, ash, crude fibre, protein, crude fat and carbohydrate was determined by difference. Calcium, magnesium, potassium, phosphorus and sodium were analyzed using the dry-ash techniques according to AOAC (2005). The method described by Mpotokwane et al. (2008) was adopted for the determination of bulk density with slight 
modification. Water and oil absorption capacity of the flour was determined as described by Oyeyinka et al. (2013). The swelling power and solubility index of the composite flour was determined according to the method described by Sanni et al. (2008). The tannin content of the cookies was determined by AOAC (2005) using Folin Denis Reagents. Phytate content was determined using AOAC (2005). Oxalate was determined by the titration method of Nwinuka et al. (2005) and Saponins determination was carried out by Fenwick and Oakenfull (1983).

\subsection{Physical attributes of cookies}

The weight and diameter of the cookie samples were determined by weighing on a weighing balance (Santual Electronic Weighing Balance) and measuring with a calibrated ruler, respectively (AOAC, 2005). Cookies spread ratio was determined according to the method of Giami et al. (2004). The thickness of the cookies was determined using the method of Mcwatters et al. (2003). Break strength was determined according to the method described by Okaka and ISieh (1990).

\subsection{Sensory evaluation}

The sensory evaluation was carried out by fifty untrained sensory panelists of undergraduate students of Ladoke Akintola University of Technology, Nigeria. Each panelist was served with cookies made from the composite flour. Water was provided for rinsing between the samples. The organoleptic attributes assessed include colour, taste, aroma, crispiness and overall acceptance of the cookies using the 9-point hedonic scale with 1 dislike extremely and 9 like extremely.

\subsection{Statistical analysis}

The results of the experiment were subjected to analysis of variance (ANOVA) and the mean was separated with the use of Duncan's multiple range test to determine the significant difference $(p<0.05)$ among the sample.

\section{Results and discussion}

3.1 Results of the proximate composition of the composite flour

The proximate composition of composite flour is shown in Table 1. The moisture content of the composite flour ranged from 7.85 to $9.71 \%$ with the control sample (100\% wheat flour) having the lowest and sample 50/30/20 wheat, acha and African yam bean having the highest value. The result of the moisture content of the flour varies as acha and African yam bean flour is added. The moisture content of the flour is within an acceptable limit for stable shelf life as reported by Kayisu et al. (1981). Moisture content is very essential for life maintenance and analysis of it is one of the most widely used instruments which determine the way the food was processed and its shelf life (Akinsanmi et al., 2015). It has also been used as a measure of stability and susceptibility to microbial contamination. Flours with lower moisture have greater shelf stability since spoilage is often caused by microbial activities and related chemical reactions that require higher moisture levels.

The protein content of the flour ranged from 12.34 to $14.01 \%$. Sample $50 \%$ wheat flour, $30 \%$ acha flour and $20 \%$ African yam bean flour had the highest value. The highest protein content of composite flour could be attributed to the ratio of African yam bean percentage $(20 / 100 \mathrm{~g})$ in the flour component (Iwuoha and Eke, 1996; Onyenekwe et al., 2000) and high protein wheat and acha flour (Jideani and Akingbala, 1993; NRC, 1996). The fat content of the composite flour ranged from 1.15 to $1.86 \%$ with $100 \%$ wheat flour having the lowest value while 50/30/20 (wheat flour, acha flour and African yam bean flour) had the highest value. The fat content of the flour blends in this study is similar to those reported by Egbebi and Bademosi (2011) and Odenigbo et al. (2013). The lower fat gave a higher probability of a longer shelf-life in terms of the onset of rancidity (Ihekoronye and Ngoddy, 1985).

The crude fibre of the flour mixes ranged from 1.21 to $1.49 \%$. Sample with $100 \%$ acha flour having the lowest value whereas sample $50 \%$ wheat flour, $30 \%$ acha

Table 1. Proximate composition of wheat, acha and African yam bean flour blends

\begin{tabular}{ccccccc}
\hline $\begin{array}{c}\text { Sample } \\
(\text { WF/AF/AYBF \%) }\end{array}$ & Moisture (\%) & Protein (\%) & Fat (\%) & Fibre (\%) & Ash (\%) & Carbohydrate (\%) \\
\hline $100 / 0 / 0$ & $7.85 \pm 0.16^{\mathrm{a}}$ & $12.76 \pm 0.03^{\mathrm{a}}$ & $1.28 \pm 0.04^{\mathrm{a}}$ & $1.36 \pm 0.00^{\mathrm{a}}$ & $1.73 \pm 0.01^{\mathrm{b}}$ & $75.02 \pm 0.25^{\mathrm{c}}$ \\
$80 / 15 / 5$ & $9.58 \pm 0.01^{\mathrm{c}}$ & $13.48 \pm 0.01^{\mathrm{b}}$ & $1.33 \pm 0.11^{\mathrm{b}}$ & $1.41 \pm 0.02^{\mathrm{b}}$ & $1.65 \pm 0.01^{\mathrm{a}}$ & $71.55 \pm 0.08^{\mathrm{b}}$ \\
$70 / 20 / 10$ & $9.25 \pm 0.13^{\mathrm{c}}$ & $13.76 \pm 0.06^{\mathrm{b}}$ & $1.66 \pm 0.02^{\mathrm{b}}$ & $1.45 \pm 0.03^{\mathrm{b}}$ & $1.86 \pm 0.02^{\mathrm{c}}$ & $71.02 \pm 0.15^{\mathrm{b}}$ \\
$50 / 30 / 20$ & $9.71 \pm 0.12^{\mathrm{c}}$ & $14.01 \pm 0.06^{\mathrm{c}}$ & $1.86 \pm 0.03^{\mathrm{c}}$ & $1.49 \pm 0.02^{\mathrm{b}}$ & $1.92 \pm 0.02^{\mathrm{c}}$ & $70.01 \pm 0.04^{\mathrm{a}}$ \\
\hline
\end{tabular}

Values are expressed as mean \pm standard deviation. Values with different superscript within the column are significantly different $(\mathrm{p}<0.05)$.

$100 / 0 / 0=100 \%$ wheat flour; 80/15/5 = 80\% wheat flour, $15 \%$ acha flour, 5\% African yam bean flour; 70/20/10=70\% wheat flour, $20 \%$ acha flour, $10 \%$ African yam bean flour; 50/30/20 =50\% wheat flour, 30\% acha flour, $20 \%$ African yam bean flour 
flour and 20\% African yam bean flour had the highest value. Fibre content the flour blends of increased with increase in the addition of Africa yam bean and acha flour. The fiber content of the samples was higher than what Oladele et al. (2009) reported in their findings. It is well known that soluble fibre generally increases transit time through the gut, slow emptying of the stomach and slow glucose absorption (Chukwuma et al., 2010).

The ash content of the flour ranged from 1.65 to $1.92 \%$, the highest value was observed in the 50/30/20 wheat, acha and African yam bean flour whilst the 100 wheat flour were the lowest. Ash contents are an indication of minerals that are contained in the flours. Flours reported in this study are comparable with the work of Odenigbo et al. (2013). The carbohydrate content of the flour ranged from 70.01 to $76.11 \%$ with acha flour having the highest and 50/30/20 wheat, acha and African yam bean having the lowest value. The carbohydrate contents of these samples are an indication that the products are good sources of energy. Carbohydrates are good sources of energy and that a high concentration of it is desirable in breakfast meals and weaning formulas. In this regard, therefore, the high carbohydrates content of the wheat flour would make it provide required energy in breakfast formulations (Butt et al., 2010).

\subsection{Mineral composition of the composite flour}

The mineral content of the composite flour is shown in Table 2. The value ranged from 10.11-13.12 mg/100 g, 52.65-61.76 mg/100 g, 130.71-211.76 mg/100 g, $111.97-130.84 \mathrm{mg} / 100 \mathrm{~g}$ and $14.81-20.43 \mathrm{mg} / 100 \mathrm{~g}$ for calcium, magnesium, potassium, phosphorus and sodium, respectively. The samples were significantly different from one another. Minerals are important in food with high nutritional components and they are classified as essential or non-essential elements. Minerals are essential for health and as such are part of all aspect of cellular function and they are required for building structural components of human beings. Some mineral elements form an integral part of an enzyme or protein structure. They are vital for normal growth, maintenance, effective immune system and prevention of cell damage (Kassa and Hailay, 2014). The results from the mineral analysis showed that the composite flour would contribute substantially to the recommended dietary requirement for minerals.

\subsection{Functional properties of the flour}

The functional properties of the composite flour are as shown in Table 3. The bulk density of flour is the density measured without the influence of any compression. The bulk density of flour blends ranged from 0.769 to $0.805 \mathrm{~g} / \mathrm{cm}^{3}$. It is clear that decreased in the proportion of wheat flour leads to an increase in bulk density of composite flours. The high bulk density makes the flour suitable for use in food preparations. Therefore, this study shows that high bulk density of composite flour indicates its ability to be used as a thickener in food products and for use in food preparation since it helps to reduce paste thickness which is an important factor in convalescent and child feeding. Bulk density of composite flours increased significantly as acha and African yam bean flour incorporated with wheat flour increases. Similar findings were reported by Eltayeb et

Table 2. Mineral composition of flour blends from wheat, acha and African yam bean

\begin{tabular}{cccccc}
\hline $\begin{array}{c}\text { Sample } \\
(\mathrm{WF} / \mathrm{AF} / \mathrm{AYBF} \%)\end{array}$ & $\begin{array}{c}\text { Calcium } \\
\mathrm{mg} / 100 \mathrm{~g}\end{array}$ & $\begin{array}{c}\text { Magnesium } \\
\mathrm{mg} / 100 \mathrm{~g}\end{array}$ & $\begin{array}{c}\text { Potassium } \\
\mathrm{mg} / 100 \mathrm{~g}\end{array}$ & $\begin{array}{c}\text { Phosphorus } \\
\mathrm{mg} / 100 \mathrm{~g}\end{array}$ & $\begin{array}{c}\text { Sodium } \\
\mathrm{mg} / 100 \mathrm{~g}\end{array}$ \\
\hline $100 / 0 / 0$ & $13.12 \pm 0.01^{\mathrm{d}}$ & $54.71 \pm 0.92^{\mathrm{b}}$ & $141.05 \pm 0.02^{\mathrm{c}}$ & $116.91 \pm 1.10^{\mathrm{c}}$ & $16.42 \pm 0.12^{\mathrm{c}}$ \\
$80 / 15 / 5$ & $11.37 \pm 0.12^{\mathrm{b}}$ & $61.76 \pm 0.15^{\mathrm{d}}$ & $211.76 \pm 0.15^{\mathrm{e}}$ & $111.97 \pm 2.68^{\mathrm{a}}$ & $19.79 \pm 0.10^{\mathrm{d}}$ \\
$70 / 20 / 10$ & $10.11 \pm 0.03^{\mathrm{a}}$ & $59.50 \pm 0.07^{\mathrm{c}}$ & $182.66 \pm 0.28^{\mathrm{d}}$ & $130.84 \pm 0.35^{\mathrm{e}}$ & $20.43 \pm 0.10^{\mathrm{e}}$ \\
$50 / 30 / 20$ & $11.86 \pm 0.30^{\mathrm{b}}$ & $52.65 \pm 0.59^{\mathrm{a}}$ & $130.71 \pm 0.21^{\mathrm{a}}$ & $124.65 \pm 0.31^{\mathrm{d}}$ & $14.81 \pm 0.22^{\mathrm{a}}$ \\
\hline
\end{tabular}

Values are expressed as mean \pm standard deviation. Values with different superscript within the column are significantly different $(\mathrm{p}<0.05)$.

$100 / 0 / 0=100 \%$ wheat flour; $80 / 15 / 5=80 \%$ wheat flour, $15 \%$ acha flour, $5 \%$ African yam bean flour; $70 / 20 / 10=70 \%$ wheat flour, $20 \%$ acha flour, $10 \%$ African yam bean flour; 50/30/20 =50\% wheat flour, 30\% acha flour, $20 \%$ African yam bean flour

Table 3. Functional properties of wheat, acha and African yam bean flour blends

\begin{tabular}{cccccccc}
\hline $\begin{array}{c}\text { Sample } \\
(\mathrm{WF} / \mathrm{AF} / \mathrm{AYBF} \%)\end{array}$ & $\begin{array}{c}\text { Bulk density } \\
\left(\mathrm{g} / \mathrm{cm}^{3}\right)\end{array}$ & $\begin{array}{c}\text { WAC } \\
(\mathrm{g} / \mathrm{g})\end{array}$ & $\begin{array}{c}\text { OAC } \\
(\mathrm{g} / \mathrm{g})\end{array}$ & $\begin{array}{c}\text { Swelling capacity } \\
(\%)\end{array}$ & $\begin{array}{c}\text { Solubility index Wettability Dispersibility } \\
(\%)\end{array}$ & $\begin{array}{c}\text { (\%) } \\
(\%)\end{array}$ \\
\hline $100 / 0 / 0$ & $0.769^{\mathrm{a}}$ & $188.115^{\mathrm{d}}$ & $197.230^{\mathrm{d}}$ & $699.540^{\mathrm{d}}$ & $6.440^{\mathrm{b}}$ & $125.500^{\mathrm{d}}$ & $75.250^{\mathrm{c}}$ \\
$80 / 15 / 5$ & $0.774^{\mathrm{b}}$ & $89.372^{\mathrm{c}}$ & $99.090^{\mathrm{c}}$ & $593.410^{\mathrm{c}}$ & $5.680^{\mathrm{a}}$ & $85.500^{\mathrm{b}}$ & $73.750^{\mathrm{a}}$ \\
$70 / 20 / 10$ & $0.781^{\mathrm{b}}$ & $88.565^{\mathrm{b}}$ & $96.461^{\mathrm{b}}$ & $591.264^{\mathrm{b}}$ & $5.713^{\mathrm{a}}$ & $87.351^{\mathrm{c}}$ & $74.950^{\mathrm{b}}$ \\
$50 / 30 / 20$ & $0.805^{\mathrm{c}}$ & $86.650^{\mathrm{a}}$ & $94.305^{\mathrm{a}}$ & $569.230^{\mathrm{a}}$ & $6.245^{\mathrm{b}}$ & $61.500^{\mathrm{a}}$ & $75.000^{\mathrm{c}}$ \\
\hline
\end{tabular}

Values with different superscript within the column are significantly different $(\mathrm{p}<0.05)$.

$100 / 0 / 0=100 \%$ wheat flour; $80 / 15 / 5=80 \%$ wheat flour, $15 \%$ acha flour, $5 \%$ African yam bean flour; $70 / 20 / 10=70 \%$ wheat flour, $20 \%$ acha flour, $10 \%$ African yam bean flour; 50/30/20 $=50 \%$ wheat flour, 30\% acha flour, $20 \%$ African yam bean flour 
al. (2011) on chemical composition and functional properties of flour and protein isolate extracted from Bambara groundnut.

The water absorption capacity (WAC) for composite flour is given in Table 3. The WAC ranged between 86.65 to $188.11 \mathrm{~g} / \mathrm{g}$ for the flour blends. The WAC was observed to be highest in the sample with $100 \%$ wheat flour and lowest in 50/30/20 wheat, acha, African yam bean flour. The result shows that the addition of acha and African yam bean flour to wheat flour has effects on the amount of water absorption. This could be as a result of the molecular structure of the starch of the grain which prevented water absorption, as could be seen from the lower values of WAC, with the increase in proportions of other flours compared to wheat flours. A similar observation was reported by Kaushal et al. (2012). High WAC of composite flours shows that the flours can be used in the preparation of some foods such as sausage, dough, processed cheese and bakery products.

The oil absorption capacity (OAC) of composite flour ranged from 94.31 to $197.23 \mathrm{~g} / \mathrm{g}$ (Table 3). The highest OAC has observed in $100 \%$ wheat flour whilst the lowest value in 50/30/20 wheat, acha, African yam bean flour. The OAC of composite flour differed significantly $(\mathrm{p}<0.05)$. The presence of high-fat content in flours might have affected adversely the OAC of the composite flours. However, the flours in this study are potentially useful in the interaction of structural components in food most especially in flavour retention, improvement of palatability and extension of shelf life particularly in bakery or meat products where fat absorption is desired (Aremu et al., 2007).

The swelling capacity of flour blends ranged between 569.23 and $699.54 \%$ with sample $100 / 0 / 0$ wheat, acha, African yam bean flour having the highest and 50/30/20 wheat, acha, African yam bean flour the lowest. The swelling capacity of flours depends on types of variety, size of particles and types of processing methods or unit operations. The swelling capacity of composite flours decreased as the level of incorporation ratio of acha and African yam bean increased.

The solubility index (SI) of the flour mixes ranged from 5.68 to $6.44 \%$. It was observed that there was a significant decrease in SI as the percentage of inclusion in acha and African yam bean flour increased in the composite flour and this may be due to the large quantity of polysaccharides from the flours. Solubility index (SI) according to Spinello et al. (2014) serves as an indicator to measure the degradation of molecular components (starch). It determines the amount of free polysaccharide or polysaccharide released from the granules after the addition of excess of water. Spinello et al. (2014) also reported that SI depends on the intensity, type of reaction that occurs and the temperature of the extruder during extrusion which may have influenced the amount of soluble molecules.

The wettability of the flour blends ranged between 61.50 and $125.50 \mathrm{~s}$. There were significant $(\mathrm{p}<0.05)$ differences among the blends. Wettability reduced as percentage inclusion of acha and African yam bean flour increased. From the results obtained, less than $60 \mathrm{~s}$ is required by the flour blends to be fully wet.

The dispersibility of flour blends ranged from 73.75 to $75.25 \%$. There was no significant $(\mathrm{p}<0.05)$ difference among the blends. Dispersibility is an index that measures how well flour or flour blends can be rehydrated with water. The higher the dispersibility values the better and easier the reconstitution of flour (Kulkani et al., 1991; Adebowale et al., 2008). Since the dispersibility value for all the flour blends is relatively high, it implies that they will reconstitute easily to fine consistent dough during mixing.

\subsection{Anti-nutritional factors of the flour}

The result of the anti-nutrient composition of flour blends is shown in Table 4. The presence of antinutrients in foods could hinder the efficient utilization, absorption or digestion of some nutrients and thus, reduce their bioavailability (Adeniji et al., 2007). Oxalate content ranged from 37.67 to $46.73 \mathrm{mg} / 100 \mathrm{~g}$. The study had shown that oxalates in large amounts bind with calcium forming calcium oxalate, which is insoluble and not absorbed by the body (Taiwo et al., 2017). Oxalates are considered poisonous at high concentration, but harmless when present in small amounts (Chai and Liebman, 2004). The phytate content varied from 5.27 to $5.57 \mathrm{mg} / 100 \mathrm{~g}$ also increased as the addition of African yam bean and acha flour increased. Phytic acid is the main phosphorus store in mature seeds with a strong binding capacity. Agte et al. (1997) described that cereal processing such as soaking of cereal flour prior to heating helps to activate phytases and therefore help zinc availability due to the processing techniques used which required heat. Ojo and Akande (2013) reported that various food processing techniques such as cooking, soaking and autoclaving helps in reducing the antinutritional factor of foods. This could mean that the reduction in phytate content will provide a great impact on the availability of zinc. The tannin values ranged from 32.91 to $35.10 \mathrm{mg} / 100 \mathrm{~g}$ increased as a percentage of the addition of African yam bean and acha flour increased. Tannins are polyhydric phenols majorly founds in all parts of plants and are known to lower the activities chymotrypsin, trypsin, lipase and amylase (Inyang and Ekop, 2015). The observed presence and quantity of 
tannins in all the samples can be of great medical

Table 4. Anti-nutritional factors of wheat, acha and African yam bean flour

\begin{tabular}{cccc}
\hline $\begin{array}{c}\text { Sample } \\
(\mathrm{WF} / \mathrm{AF} / \mathrm{AYBF} \%)\end{array}$ & $\begin{array}{c}\text { Oxalate } \\
(\mathrm{mg} / 100 \mathrm{~g})\end{array}$ & $\begin{array}{c}\text { Phytate } \\
(\mathrm{mg} / 100 \mathrm{~g})\end{array}$ & $\begin{array}{c}\text { Tannin } \\
(\mathrm{mg} / 100 \mathrm{~g})\end{array}$ \\
\hline $100 / 0 / 0$ & $37.675^{\mathrm{a}}$ & $5.546^{\mathrm{b}}$ & $32.915^{\mathrm{a}}$ \\
$80 / 15 / 5$ & $41.950^{\mathrm{b}}$ & $5.272^{\mathrm{a}}$ & $33.790^{\mathrm{b}}$ \\
$70 / 20 / 10$ & $43.550^{\mathrm{c}}$ & $5.316^{\mathrm{a}}$ & $34.450^{\mathrm{c}}$ \\
$50 / 30 / 20$ & $46.730^{\mathrm{d}}$ & $5.573^{\mathrm{b}}$ & $35.100^{\mathrm{d}}$ \\
\hline
\end{tabular}

Values with different superscript within the column are significantly different $(\mathrm{p}<0.05)$.

$100 / 0 / 0=100 \%$ wheat flour; $80 / 15 / 5=80 \%$ wheat flour, $15 \%$ acha flour, 5\% African yam bean flour; 70/20/10 =70\% wheat flour, 20\% acha flour, $10 \%$ African yam bean flour; $50 / 30 / 20=50 \%$ wheat flour, 30\% acha flour, $20 \%$ African yam bean flour

importance since tannins serve as good antioxidant.

\subsection{Physical properties of cookies}

The physical properties values ranged from 6.11 $6.85 \mathrm{~mm}, 38.46$ - $39.55 \mathrm{~mm}, 37.65$ - $38.23 \mathrm{~mm}, 4.79$ $5.85 \mathrm{~mm}, 5.35-6.49 \mathrm{~mm}$ and $1.72-1.90 \mathrm{~mm}$ for thickness, diameter, height, spread ratio, weight and break strength respectively (Table 5). There was a significant $(p<0.05)$ difference in the physical properties of the cookie samples. The thickness of the cookies increased with the increase of addition of acha and African yam bean flour in the cookie formulation. Values for height increased with increase in the level of composite flour, while the weight of the cookies decreased with increase in the level of acha and African yam bean flour in the formulation. This may be owing to the rise in the protein content from the incorporation of the flours. Spread ratio or diameter is used to determine the quality of flour used in preparing cookies and the ability of the cookies to rise (Bala et al., 2015). The higher the spread ratio of cookies the more desirable it is (Chauhan et al., 2016). Hence, cookies prepared from $80 \%$ wheat flour, $15 \%$ acha flour and $5 \%$ African yam bean flour may be the most preferred based on spread ratio. Similar findings with respect to the weight, diameter, and spread ratio were reported by other researchers (Mridula et al., 2007; Oluwamukomi et al., 2011).

The weight of cookies produced from different flour blends differs significantly from the sample with $100 \%$ wheat flour. Their weights decreased with increased substitution of wheat flour with acha and African yam bean flours. This decrease in weight may be owing to the increase in the fat content of the samples as indicated in the fat content of the samples and/ or a decrease in the moisture content. These results are in line with Ayo et al. (2007). The break strength of the cookies decreased from 1.90 to $1.72 \mathrm{~kg}$ as the percentage of acha and African yam beans were increased. The sample $100 \%$ wheat flour had the highest break strength and sample with $50 \%$ wheat flour, $30 \%$ acha flour, $20 \%$ African yam bean flour was the most fragile. This may be due to the inclusion of acha and African yam bean flour.

\subsection{Sensory properties of cookies}

The mean sensory results for all the quality attributes evaluated are shown in Table 6 . All the sensory attributes

Table 5. Physical properties of cookies prepared from flour blends of wheat, acha, and African yam bean

\begin{tabular}{ccccccc}
\hline $\begin{array}{c}\text { Sample } \\
(\text { WF/AF/AYBF \%) }\end{array}$ & Thickness (mm) & Diameter $(\mathrm{mm})$ & Height (mm) & Spread ratio & Weight (g) & Break strength (kg) \\
\hline $100 / 0 / 0$ & $6.11^{\mathrm{a}}$ & $38.46^{\mathrm{a}}$ & $37.83^{\mathrm{a}}$ & $5.74^{\mathrm{c}}$ & $6.49^{\mathrm{b}}$ & $1.90^{\mathrm{b}}$ \\
$80 / 15 / 5$ & $6.43^{\mathrm{a}}$ & $38.74^{\mathrm{a}}$ & $37.92^{\mathrm{a}}$ & $5.85^{\mathrm{c}}$ & $5.35^{\mathrm{a}}$ & $1.80^{\mathrm{b}}$ \\
$70 / 20 / 10$ & $6.63^{\mathrm{a}}$ & $39.55^{\mathrm{b}}$ & $37.65^{\mathrm{a}}$ & $5.36^{\mathrm{b}}$ & $5.40^{\mathrm{a}}$ & $1.75^{\mathrm{a}}$ \\
$50 / 30 / 20$ & $6.85^{\mathrm{b}}$ & $39.30^{\mathrm{b}}$ & $38.23^{\mathrm{b}}$ & $4.79^{\mathrm{a}}$ & $5.42^{\mathrm{a}}$ & $1.72^{\mathrm{a}}$ \\
\hline
\end{tabular}

Values are expressed as mean \pm standard deviation. Values with different superscript within the column are significantly different $(\mathrm{p}<0.05)$.

$100 / 0 / 0=100 \%$ wheat flour; $80 / 15 / 5=80 \%$ wheat flour, $15 \%$ acha flour, $5 \%$ African yam bean flour; 70/20/10 $=70 \%$ wheat flour, $20 \%$ acha flour, $10 \%$ African yam bean flour; 50/30/20 =50\% wheat flour, $30 \%$ acha flour, $20 \%$ African yam bean flour

Table 6. Mean sensory scores of cookie samples

\begin{tabular}{cccccc}
\hline $\begin{array}{c}\text { Sample } \\
(\text { WF/AF/AYBF \%) }\end{array}$ & Colour & Taste & Aroma & Crispness & Overall Acceptability \\
\hline $100 / 0 / 0$ & $6.891^{\mathrm{b}}$ & $6.978^{\mathrm{b}}$ & $6.804^{\mathrm{b}}$ & $6.935^{\mathrm{b}}$ & $7.261^{\mathrm{b}}$ \\
$80 / 15 / 5$ & $6.521^{\mathrm{a}}$ & $6.742^{\mathrm{b}}$ & $6.546^{\mathrm{a}}$ & $6.174^{\mathrm{a}}$ & $6.717^{\mathrm{a}}$ \\
$70 / 20 / 10$ & $6.304^{\mathrm{a}}$ & $6.587^{\mathrm{a}}$ & $6.304^{\mathrm{a}}$ & $6.355^{\mathrm{a}}$ & $6.825^{\mathrm{a}}$ \\
$50 / 30 / 20$ & $6.717^{\mathrm{b}}$ & $6.543^{\mathrm{a}}$ & $6.435^{\mathrm{a}}$ & $6.478^{\mathrm{a}}$ & $6.913^{\mathrm{a}}$ \\
\hline
\end{tabular}

Values with different superscript within the column are significantly different $(\mathrm{p}<0.05)$.

$100 / 0 / 0=100 \%$ wheat flour; $80 / 15 / 5=80 \%$ wheat flour, $15 \%$ acha flour, $5 \%$ African yam bean flour; $70 / 20 / 10=70 \%$ wheat flour, $20 \%$ acha flour, $10 \%$ African yam bean flour; 50/30/20 =50\% wheat flour, $30 \%$ acha flour, $20 \%$ African yam bean flour 
of the cookies decreased with increased substitution of wheat flour with acha and African yam beans. The cookies made with composite flours with a higher percentage of African yam beans had beany flavour which resulted to lower flavour ratings compared to cookies from $100 \%$ wheat. The colour of cookies became darker with increased substitution of the wheat flour with acha and African yam beans; from creamy to dark brown. All the cookies were however accepted with respect to all the parameters assessed using the ninepoint Hedonic scale.

\section{Conclusion}

This study determined the proximate, minerals, functional and anti-nutritional properties of flour with the physical and sensory attributes of cookies. Cookies of acceptable quality were produced from composite flours of wheat, acha and African yam beans. The cookies produced have increased nutrient contents which are all desirable for good health and wellbeing. The study shows that supplementation of wheat with $30 \%$ acha and 20\% African yam beans produced well accepted cookies. The use of acha and African yam beans in cookies will go a long way in enhancing nutrition, health and wellbeing of the consumers and reduce the dependence on wheat flour, thereby saving the huge foreign exchange used in importing wheat, for other projects. It will also reduce food insecurity and diversify the use of acha and African yam bean.

\section{References}

Adebowale, A.A., Sanni, L.O. and Ladapo, F.O. (2008). Chemical, functional and sensory properties of instant yam-breadfruit. Nigerian Food Journal, 26 (1), 2-12. https://doi.org/10.4314/nifoj.v26i1.47417

Adegoke, G.O. (2004). Understanding Food Microbiology, 2nd ed. Ibadan, Nigeria: Shalom Press.

Adeniji, T.A., Sanni, L.O., Barimalaa, I.S. and Hart, A.D. (2007). Anti-nutrients and heavy metals in some new plantain and banana cultivars. Nigerian Food Journal, 25(2), 165-170. https:// doi.org/10.4314/nifoj.v25i1.33666

Adoukonou-Sagbadja, H., Wagner, C., Dansi, A., Ahlemeyer, J., Daïnou, O., Akpagana, K. and Friedt, W. (2007). Genetic diversity and population differentiation of traditional fonio millet (Digitaria spp.) landraces from different agro-ecological zones of West Africa. Theoretical and Applied Genetics, 115(7), 917-931. https://doi.org/10.1007/s00122-007 $-0618-\mathrm{x}$
Agte, V.V., Gokhale, M.K. and Chiplonkar, S.A. (1997) Effect of natural fermentation on in vitro zinc bioavailability in cereal-legume mixture. International Journal of Food Science and Technology, 32(1), 29-34. https://doi.org/10.1046/ j.1365-2621.1997.00372.x

Akinsanmi, A.O., Oboh, G., Akinyemi, J., Ayodele, J. and Adefegha, A.S. (2015). Assessment of the nutritional and antioxidant capacity of unripe, ripe and over ripe plantain (Musa paradisiaca) peels. International Journal of Advanced Research, 3(2), $63-72$.

Akpapunam, M.A. and Darbe, J.W. (1994). Chemicalcomposition and functional- properties of blends of maize and Bambara groundnut ours for cookie production. Plant Foods for Human Nutrition, 46(2), 147 - 155. https://doi.org/10.1007/BF01088767

AOAC. (2005). Official Methods of Analysis, 22nd ed. Washington DC, USA: Association of Analytical Chemist.

Aremu, M.O, Olaofe O. and Akintayo, E.T. (2007). Functional properties of some Nigerian varieties of legume seed flour concentration effect on foaming and gelation properties. Journal of Food Technology, 5(2), 109-115.

Ayo, J.A., Ayo, V.A., Nkama, I. and Adewi, R. (2007). Physical, in vitro digestibility and organoleptic evaluation of Acha-wheat biscuit supplemented with soybean flour. Nigerian Food Journal, 25(1), 77-89. https://doi.org/10.4314/nifoj.v25i1.33656

Azeke, M. A., Fretzdorff, B., Buening-Pfaue, H., Holzapfel, W. and Betsche, T. (2005). Nutritional value of African yam bean (Sphenostylis stenocarpa $L$ ): improvement by lactic acid fermentation. Journal of the Science of Food and Agriculture, 85(6), 963970. https://doi.org/10.1002/jsfa.2052

Bala, A., Gul, K. and Riar, C.S. (2015). Functional and sensory properties of cookies prepared from wheat flour supplemented with cassava and water chestnut flours. Cogent Food and Agriculture, 1, $1019815 . \quad$ https:// doi.org/10.1080/23311932.2015.1019815

Barikmo I., Quattara F. and Oshaug A. (2004). Protein, carbohydrate and fibre in cereals from Mali - how to fit the results in a food composition table and database. Journal of Food Composition and Analysis, 17(3-4), 291-300. https://doi.org/10.1016/ j.jfca.2004.02.008

Butt, M.S. and Batool R. (2010). Nutritional and functional properties of some promising legumes proteins isolates. Pakistan Journal of Nutrition, 9(4), 373-379. https://doi.org/10.3923/pjn.2010.373.379 
Ceserani, V. and Kinton, R. (2008). Practical Cookery. 10th ed. New York: John Wiley and Sons.

Chai, W. and Liebman, M. (2004). Assessment of oxalate absorption from Almonds and Black beans with and without the use of an extrinsic label. The Journal of Urology, 172(3), 953-957. https:// doi.org/10.1097/01.ju.0000135918.00761.8a

Chauhan, A., Saxena, D.C. and Singh, S. (2016). Physical, textural and sensory characteristics of wheat and amaranth flour blend cookies. Cogent Food and Agriculture, 2, 1125773. https://doi.org/10.1080/2331 1932.2015.1125773

Chukwuma, E.R., Obioma, N. and Ononogbu Ikpendu Christopher, O.I. (2010). The phytochemical composition and some biochemical effects of Nigerian Tigernut (Cyperus esculentus L.) Tuber. Pakistan Journal of Nutrition, 9(7), 709-715. https:// doi.org/10.3923/pjn.2010.709.715

Day, L. (2013). Protein from land plants potential resources for human nutrition and food security. Trend in Food Science and Technology, 32(1), 2542. https://doi.org/10.1016/j.tifs.2013.05.005

Egbebi, O. and Bademosi, T.A. (2011). Chemical composition of unripe and ripe plantain. International Journal of Tropical Medicine and Public Health, 1, 1-4.

Eltayeb, A.R.S.M., Ali, A.O. and Abou-Arab, A.S.F.M. (2011). Chemical composition and functional properties of flour and protein isolate extracted from Bambara ground nut (Vigna subterranean). African Journal of Food Science, 2011, 5(2), 82-90.

Enwere, N.J. (1998). Foods of plant origin. Nsukka, Nigeria. Afro-Orbis Publication, Ltd.

Fenwick, D.E. and Oakenfull, D. (1983). Saponin content of food plants and some prepared foods. Journal of the Science of Food and Agriculture, 34 (2), 186-191. https://doi.org/10.1002/ jsfa.2740340212

Giami, S.Y., Amasisi, T. and Ekiyor, G. (2004). Comparison of bread making properties of composite flour from kernels of roasted and boiled African breadfruit (Treculia Africana decne) seeds. Journal Raw Material Resources, 1, 16-25.

Ihekoronye, A.I. and Ngoddy, P.O. (1985). Integrated Food Science and Technology, p. 296 - 301. New York: Macmilian Publishers.

Ikhtiar, K. and Alam, Z. (2007). Nutritional composition of Pakistani wheat varieties. Journal of Zhejiang University SCIENCE B, 8(8), 555-559. https:// doi.org/10.1631/jzus.2007.B0555

Inyang, U.F. and Ekop, V.O. (2015). Physico-chemical properties and anti-nutrient contents of unripe banana and African yam bean flour blends. International Journal of Nutrition and Food Sciences, 4(5), 549-554. https://doi.org/10.11648/ j.ijnfs. 20150405.16

Iwuoha, C.I. and Eke, O.S. (1996). Nigerian indigenous fermented foods: their traditional process operation, inherent problems, improvements and current status. Food Research International, 29(5-6), 527-540. https://doi.org/10.1016/0963-9969(95)00045-3

Jideani, I.A and Akingbala, J.O. (1993). Some physical properties of acha (Digitaria exilis) and Iburu (Digitaria iburua) Grains. Journal of Science Food and Agriculture, 63, 369-373. https:// doi.org/10.1002/jsfa.2740630317

Kassa, B. and Hailay, K. (2014). Determination of trace metals Oliefera using atomic absorption spectroscopy. Journal of Biology, Agriculture and Healthcare, 4(17), 52-55.

Kaushal, P., Kumar, V. and Sharma, H.K. (2012). Comparative study of physico-chemical, functional, anti-nutritional and pasting properties of taro (Colocasia esculenta), rice (Oryza sativa), pigeon pea (Cajanus cajan) flour and their blends. LWTFood Science and Technology, 48(1), 59-68. https:// doi.org/10.1016/j.lwt.2012.02.028

Kayisu, K., Hood, L.F. and Vansoest, P.J. (1981). Characterization of starch and fiber of banana fruit. Journal of Food Science, 46(6), 1885-1890. https:// doi.org/10.1111/j.1365-2621.1981.tb04511.x

Kulkarni, S.D. (1997). Roasted soybean in cookies: Influence on product quality. Journal of Food Science and Technology-mysore, 34, 503-505.

McWatters, K.H., Ouedraogo, J.B., Resurreccion, A.V.A., Hung, Y.C. and Phillips, R.D. (2003). Physical and sensory characteristics of sugar cookies containing mixtures of wheat, fonio (Digitaria exilis) and cowpea (Vigna unguiculata) flours. International Journal of Food Science and Technology, 38(4), 403-410. https:// doi.org/10.1046/j.1365-2621.2003.00716.x

Mpotokwane, S.M., Gaditlhatlhelwe, E., Sebaka, A. and Jideani, V.A. (2008). Physical properties of bambara groundnuts from Botswana. Journal of Food Engineering, 89(1), 93-98. https://doi.org/10.1016/ j.jfoodeng.2008.04.006

Mridula, D., Goyal, R.K., Bhargar, V.K. and Manikantan, M.R. (2007). Effect of roasting on texture, colour, and acceptability of soybean for making sattu. American Journal of Food Technology, 2(4), 265-272. https://doi.org/10.3923/ ajft.2007.265.272

NRC. (1996) Grains. Fonio (Acha), In Lost crops of 
Africa. Vol. 1, p. 59-75. Washington, DC, USA: National Academy Press, National Research Council Washington.

Nwinuka, N.M., Ibeh, G.O. and Ekeke, G.I. (2005). Proximate composition and levels of some toxicants in four commonly consumed spices. Journal of Applied Science and Environmental Management, 9 (1), 150-155.

Odenigbo, M.A., Asumugha, V.U., Ubbor, S., Nwauzor, C., Otuonye, A.C., Offia-Olua, B.I., PrincewillOgbonna, I.L., Nzeagwu, O.C., Henry-Uneze, H.N., Anyika, J.U., Ukaegbu, P., Umeh, A.S. and Anozie, G.O. (2013). Proximate composition and consumption pattern of plantain and cookingbanana. British Journal of Applied Science and Technology, 3(4), 1035-1043. https:// doi.org/10.9734/BJAST/2013/4943

Ojo, A. and Akande, E.A. (2013). Quality evaluation of 'gari' produced from cassava and potato tuber mixes. African Journal of Biotechnology, 12, 4920-4924. https://doi.org/10.5897/AJB12.2504

Okaka, J.C. and Isieh, M.I. (1990). Development and quality evaluation of cowpea-biscuits. Nigerian Food Journal, 8, 56-62.

Oladele, K.A., Osundahunsi, F.O. and Adebowale A.Y. (2009). Influence of processing techniques on the nutrients and antinutrients of Tigernut (Cyperus esculentus L.). World Journal of Dairy and Food Sciences, 4(2), 88-93. https://doi.org/10.4314/ nifoj.v27i2.47492

Olaoye, O.A., Onilude, A.A. and Oladoye, C.O. (2007). Breadfruit flour in biscuit making: effects on product quality. African Journal of Food Science, 1, 20-23.

Oluwamukomi, M.O., Oluwalana, I.B. and Akinbowale, O.F. (2011). Physicochemical and sensory properties of wheat-cassava composite biscuit enriched with soy flour. African Journal of Food Science, 5(2), 5056.

Onyenekwe, P.C., Njoku, G.C. and Ameh, D.A. (2000). Effect of cowpea (Vigna unguiculata) processing methods on flatus causing oligosaccharides. Nutrition Research, 20(3), 349 - 358. https:// doi.org/10.1016/S0271-5317(00)00128-7

Oyeyinka, S.A., Oyeyinka, A.T., Karim, O.R., Kayode, R.M.O., Balogun, M.A. and Balogun O.A. (2013). Quality attributes of Weevils (Callosobruchus maculatus) infested cowpea (Vigna unguiculata) products. Nigerian Journal of Agriculture, Food and Environment, 9(3), 16-22.

Sanni, L.O., Adebowale, A.A., Awoyale, W. and Fetuga, G.O. (2008). Quality of gari (roasted cassava mash) in Lagos State, Nigeria. Nigerian Food Journal, 26
(2), 125-134.

https://doi.org/10.4314/ nifoj.v26i2.47446

Spinello, A.M., Mageali, L., Mischan, M.M. and Ezequiel, L. (2014). Cassava and tumeric flour blends as new raw materials to extruded snack. CiencAgrotechnogie, 30, 68-75. https:// doi.org/10.1590/S1413-70542014000100008

Taiwo, E.O., Sekinat, A.A., Adegbola, D.O., Arise, A.K. and Sotunde, A.J. (2017). Chemical composition and sensory qualities of wheat-sorghum date cookies. Croatian Journal of Food Technology, Biotechnology and Nutrition, 12(1-2), 71-76. 